\title{
Aleurone flour increases red-cell folate and lowers plasma homocyst(e)ine substantially in man
}

\author{
Michael Fenech*, Manny Noakes, Peter Clifton and David Topping \\ CSIRO Health Sciences and Nutrition, PO Box 10041, Gouger Street, Adelaide BC, SA 5000, Australia \\ (Received 17 June 2004 - Revised 31 October 2004 - Accepted 19 November 2004)
}

\begin{abstract}
Aleurone flour (ALF) is a rich source of natural folate $(>500 \mu \mathrm{g} / 100 \mathrm{~g}$ wet weight). Our objective was to establish whether intake of ALF in man can significantly improve folate status and reduce plasma homocyst(e)ine. We performed a randomised, controlled intervention, of 16 weeks duration, in free-living healthy individuals (mean age 46-52 years). Participants were assigned to one of three groups: ALF, $175 \mathrm{~g}$ bread made with ALF and placebo tablet each day; PCS, $175 \mathrm{~g}$ bread made with pericarp seed coat (PCS) flour and placebo tablet each day (low-folate control); or FA, 175 g bread made with PCS flour and tablet containing $640 \mu \mathrm{g}$ folic acid each day (high-folate control). The daily folate intake contributed by the bread and tablet was $233 \mu \mathrm{g}$ in the PCS group, $615 \mu \mathrm{g}$ in the ALF group and $819 \mu \mathrm{g}$ in the FA group. The number of participants completing all phases of the PCS, ALF and FA interventions was twenty-five, twenty-five and eighteen, respectively. Plasma and red-cell folate increased significantly $(P<0.0001)$ and plasma homocyst(e)ine decreased significantly $(P<0.0001)$ in the ALF and FA groups only. Plasma folate and red-cell folate in the ALF group (mean, $95 \%$ CI) increased from baseline values of $12.9(9.9,15 \cdot 7) \mathrm{nmol} / 1$ and $509(434,584) \mathrm{nmol} / 1$ to $27 \cdot 1(22.5,31.7) \mathrm{nmol} / \mathrm{l}$ and $768(676,860)$ nmol/1, respectively. Plasma homocyst(e)ine in the ALF group decreased from $9 \cdot 1(8 \cdot 2,10 \cdot 0) \mu \mathrm{mol} / 1$ at baseline to $6.8(6 \cdot 2,7 \cdot 5) \mu \mathrm{mol} / 1$ after 16 weeks. In conclusion, moderate dietary intake of ALF can increase red-cell folate and decrease plasma homocyst(e)ine substantially.
\end{abstract}

Aleurone: Bread: Folate: Folic acid: Homocyst(e)ine: Man

Inadequate intake of folate is recognised as a risk factor for neural tube defects in the developing fetus (MRC Vitamin Study Research Group, 1991; Czeizel \& Dudas, 1992) and is an important cause of anaemia (Wagner, 1995). Furthermore, chromosome aberrations in cells, a risk factor for cancer (Blount et al. 1997; Bonassi et al. 2000; Fenech, 2001), and plasma homocyst(e)ine, a risk factor for CVD (Kang et al. 1992; Boushey et al. 1995; Law, 2000; Rasmussen et al. 2000), are both increased when blood folate levels are sub-optimal. Consequently, the RDA for folate has been revised to a level of $400 \mu \mathrm{g} / \mathrm{d}$ (Cuskelly et al. 1996; Daly et al. 1997; Stevenson et al. 2000). It has also been suggested that a higher intake of folate may be required in those individuals who cannot metabolise folate efficiently due to mutations in key genes such as methylenetetrahydrofolate reductase required for the synthesis of methyltetrahydrofolate, which acts as a methyl donor to homocyst(e)ine in the synthesis of methionine (Molloy et al. 1997; Rosenberg \& Rosenberg, 1998).

Supplementation with folic acid (FA) can effectively raise blood folate, minimise the risk for neural tube defects and lower plasma homocyst(e)ine levels (Cuskelly et al. 1996; Daly et al. 1997; Molloy et al. 1997; Chambers et al. 2000; Rasmussen et al. 2000; Stevenson et al. 2000). However, the evidence that a similar outcome can be reliably obtained by natural sources from foods remains equivocal. Early studies had suggested that folate from vegetables and cereals may not be as bioavailable as folic acid given as a supplement (Gregory, 1995; Cuskelly et al.
1996). More recent studies have shown that the bioavailability of folate from fruits and vegetables as well as aleurone flour (ALF) may be $>60 \%$ of that for folic acid from a tablet (Brouwer et al. 1999; Fenech et al. 1999).

Our research has focused on the bioavailability of folate from the aleurone layer of the wheat grain. The aleurone layer of cells provides the key micronutrients for growth of the embryo during germination (Saxelby \& Venn-Brown, 1980) and is particularly noted for its high level of folate $(>500 \mu \mathrm{g} / 100 \mathrm{~g}$ wet weight; Fenech et al. 1999). Using a novel milling technology it has become economically viable to isolate the aleurone layer of cells from the pericarp seed coat (PCS) and the starchy endosperm to produce ALF (Stenvert, 1995, 1997; Fig. 1). ALF is now available on international markets and is being used for making breads that are naturally rich in folate.

Our initial studies showed that the increase in plasma folate over the $7 \mathrm{~h}$ period following ingestion of $100 \mathrm{~g}$ ALF was more than fourfold greater than that for $100 \mathrm{~g}$ wheat bran and equivalent to that observed following intake of $500 \mu \mathrm{g}$ folic acid taken with $100 \mathrm{~g}$ wheat bran (Fenech et al. 1999). We therefore performed a long-term (16 weeks), randomised, controlled intervention to verify the incremental effect of ALF ingestion on plasma folate concentration and determine whether moderate ALF intake can also substantially increase red-cell folate and reduce plasma homocyst(e)ine to an extent that is close to the maximum effect produced by taking a daily supplement containing $>500 \mu \mathrm{g}$ folic acid. 


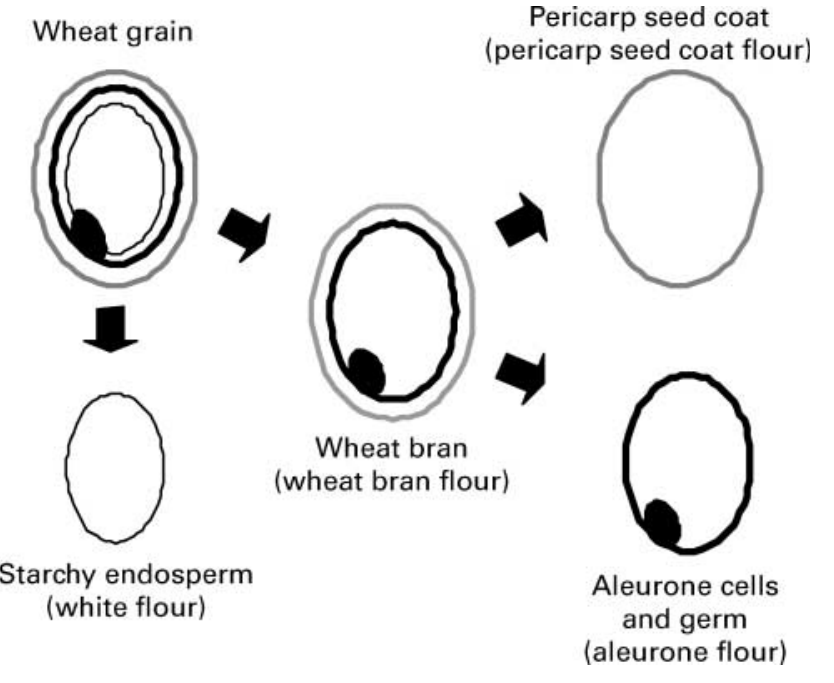

Fig. 1. A schematic diagram showing the key steps in the isolation of white flour, pericarp seed coat flour and aleurone flour.

\section{Materials and methods}

\section{Study population}

Volunteers were recruited by advertising the study in local newspapers without providing payment for participation. A total of 235 volunteers (mainly Caucasian) aged 20-70 years were screened initially for plasma homocyst(e)ine, red-cell folate and plasma vitamin $\mathrm{B}_{12}$ concentrations. We included individuals with plasma homocyst(e)ine above the 50th percentile (median) and red-cell folate below the 50th percentile (median). We excluded volunteers with low levels of plasma vitamin $\mathrm{B}_{12}(<150 \mathrm{pmol} /$ $1)$, and/or who were taking folate and vitamin $B_{12}$ supplements above the Australian recommended dietary intake levels (i.e. $>200 \mu \mathrm{g}$ folic acid/d, $>2 \mu \mathrm{g}$ vitamin $\mathrm{B}_{12} / \mathrm{d}$ ), and/or who were epileptic and on anticonvulsant therapy, and/or who had a past or present history of cancer or pernicious anaemia. Of the initial 235 volunteers screened, only seventy-nine met the selection criteria described above and these individuals were invited to participate in the study. The purpose of the study and their involvement was explained to the volunteers in a series of information sessions. Informed consent was subsequently obtained from all subjects. Three volunteers withdrew before the start of the intervention and sixty-eight completed every phase of the intervention. Withdrawal and lack of attendance to all appointments was due to travel difficulties, change in home address and other unexpected changes in personal schedules.

\section{Study design}

The study was designed as a randomised, controlled intervention in a free-living, middle-aged healthy population, comparing the effect of a high-folate bread made with ALF with that of a lowfolate bread made with PCS flour and that of a folic acid tablet given with the low-folate PCS bread. The appearance and texture of the ALF and PCS breads were similar. Volunteers were assigned to the three dietary groups using a randomised block design based on screening plasma homocyst(e)ine concentration. The dietary groups were: ALF group, ALF bread plus placebo tablet; PCS group, PCS bread plus placebo tablet (low-folate con- trol group); and FA group, PCS bread plus folic acid tablet (highfolate control group).

The breads (supplied by Goodman Fielder Milling and Baking Pty Ltd, Summerhill, Sydney, NSW, Australia) were balanced for starch and fibre content and were kept stored frozen at $-20^{\circ} \mathrm{C}$ until required. ALF bread contained $38.5 \mathrm{~g}$ ALF and $20.1 \mathrm{~g}$ white flour per $100 \mathrm{~g}$ (wet weight) in comparison to PCS bread, which contained $11.3 \mathrm{~g}$ PCS flour and $57.6 \mathrm{~g}$ white flour per $100 \mathrm{~g}$ (wet weight). The folate content, expressed as the mean of triplicate measurements, of ALF bread and PCS bread was 340 (SEM 9) $\mu \mathrm{g} / 100 \mathrm{~g}$ (wet weight) and 112 (SEM 15) $\mu \mathrm{g} / 100 \mathrm{~g}$ (wet weight), respectively. The folate content of PCS flour and white flour relative to ALF was $24 \%$ and $3 \%$, respectively. Using the latter figures and the relative amounts of different types of flour in the ALF and PCS breads, we estimated that in ALF bread $98.5 \%$ of the folate originated from ALF and $1.5 \%$ from white flour; and in PCS bread $61.8 \%$ of the folate content was due to the PCS flour and $38.2 \%$ was contributed by white flour. The ALF and PCS breads were cut into $70 \mathrm{~g}$ (wet weight) slices, which contained approximately $238 \mu \mathrm{g}$ and $78 \mu \mathrm{g}$ folate per slice, respectively. ALF and PCS breads were similar with regard to protein content $(10.5,7.8 \mathrm{~g} / 100 \mathrm{~g}$ wet weight), starch $(26.6,31.0 \mathrm{~g} / 100 \mathrm{~g}$ wet weight), total dietary fibre $(7.2,7.0 \mathrm{~g} /$ $100 \mathrm{~g}$ wet weight) and sugars $(4 \cdot 2,4.3 \mathrm{~g} / 100 \mathrm{~g}$ wet weight). Folic acid (mean of duplicate measurements) in the folic acid tablet and the placebo tablet was $640 \mu \mathrm{g}$ and $26 \mu \mathrm{g}$, respectively. Tablets were supplied by Blackmore's Ltd (Balgowlah, NSW, Australia). Breads and tablets were provided each fortnight to volunteers who kept the bread frozen until use.

Volunteers were requested to eat 2.5 slices ( $175 \mathrm{~g}$ wet weight) of the provided bread per day and ingest one tablet per day of the tablets provided. They were also asked to keep to their customary diet and to refrain from ingesting folic acid supplements or foods that were supplemented with folic acid. The dose of the folic acid supplement in the tablet was chosen to produce a maximum effect on lowering of plasma homocyst(e)ine (Rydlewicz et al. 2002; van Oort et al. 2003). The level of ALF or PCS flour in bread and the amount of bread eaten per day were the maximum possible without compromising palatability and compliance during the intervention. We chose PCS bread as the low-folate control to balance for starch and fibre content and thus minimise the possible effect of differences in bowel fermentation on folate status (Rong et al. 1991). The low level of folic acid in the placebo tablet was unintended and caused by contamination with folic acid during formulation of the tablets.

The intervention was of 16 weeks' duration to maximise the detection of red-cell folate changes because red blood cells have a life-span of 120 days (Cooper \& Jandl, 1972). Blood samples were collected just before the start of the intervention and at $28 \mathrm{~d}$ intervals thereafter. Red-cell and plasma folate, plasma homocyst(e)ine and vitamin $\mathrm{B}_{12}$ were measured at each time point.

The study protocol was approved by the Human Ethics Experimentation Committee of CSIRO Health Sciences and Nutrition and complied with the Helsinki Declaration of 1975 as revised in 1983 (Helsinki Declaration, 1996).

\section{Measurement of dietary folate intake and compliance}

During the course of the intervention volunteers were required to keep a daily record of the consumption of the following items: 
number of slices of bread; number of tablets; number of servings of fruit juice, dried fruit, canned fruit, cooked fruit and fresh fruits; number of servings of vegetable juice, vegetable soup, cooked vegetables, salad vegetables and potatoes; number of servings of breakfast cereal including breakfast cereal with added folic acid; and number of servings of flesh foods. The results of this record were used to estimate the contribution to folate intake of other foods relative to the bread and tablet provided and to obtain a measure of compliance. Folate intake estimates were based on published food composition tables (Holland et al. 1995) as well as values obtained by analysis in the case of the test breads and tablets.

\section{Analysis of breads and tablets}

Total starch was analysed using the method of McCleary et al. (1994). Total dietary fibre was determined by the gravimetric method of Prosky et al. (1985). Fat content measurement was done according to the method of Daugherty \& Lento (1983). The total nitrogen level was determined using the method of Kirsten \& Hesselius (1983) on a Carlo Erba nitrogen analyser (Carlo Erba Strumentazione, Rodano, Milan, Italy). Free sugars were extracted with $80 \%$ aqueous methanol according to the method of Theander \& Westerlund (1986), and then quantified by HPLC using acetonitrile-water $75: 25$ as the mobile phase, a polyamine-bonded polymeric gel column (Advanced Separation Technologies Inc., Whippany, NJ, USA) and a refractive index detector (GBC Scientific Equipment, Dandenong, VIC, Australia). Ash was measured by igniting the samples in pre-weighed borosilicate glass crucibles in a muffle furnace at $515^{\circ} \mathrm{C}$ for $12 \mathrm{~h}$ and then cooling in a desiccator prior to weighing; the percentage ash weight was calculated by difference. Folic acid in tablets was measured in three separate random samples of ten tablets, which were finely ground prior to analysis, using a modification of the standard Association of Official Analytical Chemists microbiological assay (AOAC International, 1996; Scheelings, 1996; Fenech et al. 1999). Folate in three separate, finely ground bread samples (mesh size $<0.5 \mathrm{~mm}$ ) was measured using the tri-enzyme method (Rader et al. 1998) without heating and centrifugation before tri-enzyme extraction using digestion with protease, $\alpha$-amylase and chicken pancreas conjugase as described previously (Tamura et al. 1997; Shrestha et al. 2000). $\mathrm{CV}$ for duplicate samples was $<8 \%$ for all analyses.

\section{Measurement of plasma folate, red cell folate and plasma total homocyst(e)ine}

Volunteers donated their blood samples between 08.00 and 11.00 hours, after an overnight fast and before having breakfast, to minimise possible confounding effects by dietary metabolites and diurnal variation. Plasma from the EDTA blood sample and whole blood haemolysate (prepared by mixing $100 \mu$ l fresh EDTA blood with $1 \mathrm{ml}$ of a fresh solution of $0.4 \%$ ascorbic acid) were snap-frozen in liquid nitrogen and stored at $-80^{\circ} \mathrm{C}$ until analysed. Plasma folate and vitamin $B_{12}$ and red-cell folate (haemolysate) were analysed in duplicate using a radioimmunoassay kit (Quantaphase II; Bio-Rad, Hercules, CA, USA). Haematocrits of fresh blood samples were also measured in each case to enable the appropriate calculation of red-cell folate from the results obtained for the haemolysate.
Analysis of plasma homocyst(e)ine was performed according to the method of Vester \& Rasmussen (1991). Briefly, blood samples for homocyst(e)ine were collected in EDTA tubes and placed on ice, and plasma was separated within $30 \mathrm{~min}$ of collection, snap-frozen in liquid nitrogen and stored at $-80^{\circ} \mathrm{C}$ until analysed. On the day of analysis, plasma was thawed, reduced with tri- $n$-butylphosphine, proteins were precipitated and the sample derivatised with ammonium 7-fluoribenzo-2-oxa-1,3-diazole4-sulfonate. Homocyst(e)ine was detected by HPLC using fluorescence detection (DP800 chromatography system; GBC Scientific Equipment). Mercaptopropionylglycine was used as an internal standard and the calibration curve was based on measurements with human plasma to which known amounts of unbound homocyst(e)ine were added.

To minimise experimental variation, the assays were performed using a single batch of each reagent throughout the intervention and all the samples for each individual and their matching controls were analysed on the same day in the same assay run. All biochemical assays were performed in duplicate. The intra-assay $\mathrm{CV}$ for the measurement of folate, vitamin $\mathrm{B}_{12}$ and homocyst(e)ine was $3.73 \%$ (SD 0.68), 2.64\% (SD 0.45) and 3.86\% (SD 0.77), respectively. Each assay was performed by a single person and the samples were coded, so that the operator had no knowledge about the treatment group to which they belonged; the codes of the samples were revealed only after the assays were completed.

\section{Statistical analysis}

The intended aim was to have a minimum of twenty-five volunteers in each group completing the intervention, which would provide, based on standard deviation values from the screening data, $85 \%$ power to detect a change in homocyst(e)ine of $2.37 \mu \mathrm{mol} / \mathrm{l}$ and $99 \%$ power to detect a difference in red-cell folate of $200 \mathrm{nmol} / \mathrm{l}$ with $P<0 \cdot 05$. When appropriate, data were log-transformed to normalise distribution prior to statistical analysis. Comparisons between groups were performed using one-way ANOVA and the post hoc Bonferroni multiple-comparison test. To compare differences in response between groups at 16 weeks, we calculated the percentage difference relative to baseline values after adjustment of the data at 16 weeks for baseline values as recommended by Vickers \& Altman (2001). Correlation analysis between two sets of data was performed using Pearson's test. Values of $P<0.05$ were considered to be statistically significant. Prism 4.0 (GraphPad Inc., San Diego, CA, USA) and CSS Statistica (Statsoft Inc., Tulsa, OK, USA) software were used to obtain these estimates.

\section{Results}

\section{Profile of participants who completed the intervention}

The number of participants who completed every phase of the intervention was twenty-five, twenty-five and eighteen for the ALF, PCS and FA groups, respectively. Their profile, at screening, is summarised in Table 1. Age, BMI and biochemical parameters were well matched and not significantly different between groups. Mean plasma homocyst(e)ine ranged between 8.6 and $8.9 \mu \mathrm{mol} / \mathrm{l}$ and mean red-cell folate ranged between 457 and $471 \mathrm{nmol} / \mathrm{l}$. Gender ratios were similar in the ALF and PCS groups ( $48 \%$ and $52 \%$ males, respectively) but the proportion of males was lower in the FA group ( $28 \%$ males). 
Table 1. Profile, at screening, of participants who completed all stages of the intervention in each dietary group*

(Values are arithmetic means and their $95 \% \mathrm{Cl}$ or percentages $\dagger$ )

\begin{tabular}{|c|c|c|c|c|c|c|}
\hline & \multicolumn{2}{|c|}{ PCS group (n 25) } & \multicolumn{2}{|c|}{ ALF group ( $n$ 25) } & \multicolumn{2}{|c|}{ FA group ( $n 18)$} \\
\hline & Mean & $95 \% \mathrm{Cl}$ & Mean & $95 \% \mathrm{Cl}$ & Mean & $95 \% \mathrm{Cl}$ \\
\hline Plasma folate (nmol/l) & $10 \cdot 7$ & $8.5,12.9$ & $12 \cdot 7$ & $9 \cdot 7,15 \cdot 6$ & $13 \cdot 3$ & $10 \cdot 9,15 \cdot 7$ \\
\hline Red-cell folate $(\mathrm{nmol} / \mathrm{l})$ & 457 & 409,506 & 467 & 412,522 & 471 & 399,542 \\
\hline Plasma homocyst(e)ine $(\mu \mathrm{mol} / \mathrm{l})$ & 8.9 & $8 \cdot 2,9 \cdot 7$ & 8.9 & $7 \cdot 9,9.9$ & 8.6 & $7 \cdot 8,9 \cdot 5$ \\
\hline Plasma vitamin $B_{12}(p m o l / l)$ & 323 & 281,366 & 287 & 255,318 & 267 & 230,305 \\
\hline Haematocrit (\%) & $42 \cdot 2$ & $40 \cdot 7,43 \cdot 8$ & 43.0 & $41 \cdot 6,44 \cdot 5$ & $42 \cdot 1$ & $40 \cdot 6,43 \cdot 6$ \\
\hline Age (years) & $51 \cdot 8$ & $47 \cdot 8,55 \cdot 8$ & $50 \cdot 2$ & $46 \cdot 2,54 \cdot 3$ & $46 \cdot 3$ & $41 \cdot 3,51 \cdot 4$ \\
\hline $\mathrm{BMI}\left(\mathrm{kg} / \mathrm{m}^{2}\right)$ & $27 \cdot 7$ & $25 \cdot 6,29 \cdot 9$ & $26 \cdot 0$ & $24 \cdot 5,27 \cdot 5$ & $25 \cdot 9$ & $23 \cdot 8,28 \cdot 1$ \\
\hline Gender (\% males) & 52 & & 48 & & 28 & \\
\hline Smokers (\%) & 8 & & 8 & & 6 & \\
\hline
\end{tabular}

${ }^{*}$ Treatment groups: PCS group, subjects received bread made with pericarp seed coat (PCS) flour plus placebo tablet (low-folate control); ALF group, subjects received bread made with aleurone flour (ALF) plus placebo tablet; FA group, subjects received PCS bread plus folic acid tablet (high-folate control).

† Values are not significantly different between groups.

\section{Dietary record and compliance data}

The dietary record data (Table 2) showed high compliance in tablet consumption in all groups $(>95 \%)$. Mean consumption rate of the supplied breads averaged between 2.4 and 2.5 slices per day (i.e. 167-178 g wet weight), and consumption of fruit, vegetables, breakfast cereals and flesh foods was similar between groups.

\section{Folate intake}

Using the dietary record and compliance data it was possible to estimate consumption of folate in the study groups (Table 3). Total daily folate intake in the ALF group $(836 \mu \mathrm{g})$ was significantly lower than that in the FA group $(1059 \mu \mathrm{g})$ and significantly greater than that in the PCS group ( $436 \mu \mathrm{g}$; ANOVA, $P<0 \cdot 0001)$. Folate from ALF bread contributed $70 \%$ of the folate intake in the ALF group. It was evident that dietary sources other than the supplied bread and tablets provided a significant proportion of the dietary folate (between 213 and $239 \mu \mathrm{g}$ of the total) in the three groups.

Estimated folate intake from the dietary record was significantly correlated with plasma homocyst(e)ine $(r-0.55, P<0.0001)$, plasma folate $(r \quad 0.69, P<0.0001)$ and red-cell folate $(r 0.64$, $P<0.0001)$ measured at the end of the intervention. The correlation factors with estimated folate intake (plasma homocyst(e)ine, $r$ - 0.43; plasma folate, $r$ 0.56; red-cell folate, $r$ 0.47) were reduced slightly but remained significant $(P<0 \cdot 001)$ when dietary record data for the FA group were removed.

\section{Plasma and red-cell folate}

There was no change in plasma folate levels in the PCS group during the course of the intervention. However, significant increments in plasma folate occurred in the ALF and FA groups at 4 weeks and subsequent sampling times, with mean plasma folate levels increasing from 12.9 and $17.5 \mathrm{nmol} / \mathrm{l}$ at baseline to 27.1 and $40 \cdot 1 \mathrm{nmol} / \mathrm{l}$, respectively, at 16 weeks (Table 4 ). The percentage change in plasma folate at 16 weeks (adjusted for baseline level; Fig. 2(a)) in the ALF and FA groups was significantly elevated relative to that in the PCS group $(P<0.0001)$. Moreover, the increment observed in the FA group was 1.7 times greater than in the ALF group $(P<0.0001)$.

There was a $16 \%$ increment in red-cell folate at 16 weeks (relative to baseline) in the PCS group during the course of the intervention (ANOVA, $P=0 \cdot 081$ ). The increments in red-cell folate in the ALF and FA groups were much greater, achieving significant increases by 12 weeks of $50.9 \%$ and $79.2 \%$ relative to baseline, respectively (Table 4 and Fig. 2(b)). The increment differences observed at 16 weeks between groups were statistically significant for all comparisons (Fig. 2(b)). There were no significant changes in haematocrit and vitamin $B_{12}$ in any of the groups (data not shown).

Table 2. Compliance and daily dietary intake data

(Values are arithmetic means and their $95 \% \mathrm{Cl}$ )

\begin{tabular}{|c|c|c|c|c|c|c|c|}
\hline & \multicolumn{2}{|c|}{ PCS group $(n 25)$} & \multicolumn{2}{|c|}{ ALF group ( $n$ 25) } & \multicolumn{2}{|c|}{ FA group (n 18) } & \multirow[b]{2}{*}{$P($ ANOVA $)$} \\
\hline & Mean & $95 \% \mathrm{Cl}$ & Mean & $95 \% \mathrm{Cl}$ & Mean & $95 \% \mathrm{Cl}$ & \\
\hline Tablets $(n / \mathrm{d})$ & 0.96 & $0.94,0.99$ & 0.97 & $0.94,1.00$ & 0.98 & $0.97,1.00$ & 0.4881 \\
\hline Bread (slices/d) & 2.5 & $2 \cdot 3,2 \cdot 8$ & 2.5 & $2 \cdot 2,2 \cdot 7$ & $2 \cdot 4$ & $2 \cdot 1,2 \cdot 6$ & 0.6261 \\
\hline Fruit (servings/d) & 1.8 & $1 \cdot 4,2 \cdot 3$ & $2 \cdot 0$ & $1 \cdot 5,2 \cdot 4$ & $2 \cdot 1$ & $1 \cdot 5,2 \cdot 7$ & 0.9333 \\
\hline Flesh† food (servings/d) & 1.2 & $0.9,1.4$ & 1.0 & $0.9,1.2$ & 1.3 & $0.9,1.6$ & 0.3184 \\
\hline
\end{tabular}

Treatment groups: PCS group, subjects received bread made with pericarp seed coat (PCS) flour plus placebo tablet (low-folate control); ALF group, subjects received bread made with aleurone flour (ALF) plus placebo tablet; FA group, subjects received PCS bread plus folic acid tablet (high-folate control). † Meat, chicken or fish. 
Table 3. Daily folate intake $(\mu \mathrm{g})$ from supplied tablets and bread and other dietary sources during the intervention

(Values are arithmetic means and their $95 \% \mathrm{Cl}$ )

\begin{tabular}{|c|c|c|c|c|c|c|c|}
\hline & \multicolumn{2}{|c|}{ PCS group ( $n$ 25) } & \multicolumn{2}{|c|}{ ALF group $(n 25)$} & \multicolumn{2}{|c|}{ FA group (n 18) } & \multirow[b]{2}{*}{$P$ (ANOVA } \\
\hline & Mean & $95 \% \mathrm{Cl}$ & Mean & $95 \% \mathrm{Cl}$ & Mean & $95 \% \mathrm{Cl}$ & \\
\hline Tablets $†$ & 25 & $24,26^{a}$ & 25 & $25,26^{\mathrm{a}}$ & 633 & $625,641^{b}$ & $<0.0001$ \\
\hline Bread & 198 & $182,215^{a}$ & 590 & $533,647^{b}$ & 186 & $167,206^{a}$ & $<0.0001$ \\
\hline Other dietary sources & 213 & 175,250 & 220 & 188,253 & 239 & 203,275 & 0.4749 \\
\hline Total & 436 & $393,478^{a}$ & 836 & $769,903^{b}$ & 1059 & $1028,1090^{c}$ & $<0.0001$ \\
\hline
\end{tabular}

Treatment groups: PCS group, subjects received bread made with pericarp seed coat (PCS) flour plus placebo tablet (low-folate control); ALF group, subjects received bread made with aleurone flour (ALF) plus placebo tablet; FA group, subjects received PCS bread plus folic acid tablet (high-folate control).

a,b,c Mean values within a row with unlike superscript letters were significantly different.

† Values for tablets represent folic acid content.

\section{Plasma homocyst(e)ine}

Significant reductions in plasma homocyst(e)ine were observed in the ALF group and the FA group only. The maximum homocys$\mathrm{t}(\mathrm{e})$ ine reduction in the ALF group from $9 \cdot 1 \mu \mathrm{mol} / \mathrm{l}$ (at baseline) to $6.8 \mu \mathrm{mol} / 1$ was observed at 8 weeks. In the FA group homocys$\mathrm{t}(\mathrm{e})$ ine was reduced from $8.1 \mu \mathrm{mol} / \mathrm{l}$ (at baseline) to a minimum of $6.0 \mu \mathrm{mol} / 1$ at 16 weeks (Table 4). A comparison of change in plasma homocyst(e)ine (adjusted for baseline level) showed that there was no significant difference between the ALF group and the FA group at 16 weeks (Fig. 2(c)). Plasma homocyst(e)ine was negatively correlated with plasma folate at all stages of the study $(r-0.29$ to $-0.42, P<0.01)$; negatively correlated with red-cell folate only at weeks 8,12 and $16(r-0.22$ to -0.32 , $P<0.05)$; negatively correlated with plasma vitamin $\mathrm{B}_{12}$ at screening $(r-0.416, P<0.001)$ and at the start and end of the intervention $(r-0.241$ and $-0 \cdot 267$, respectively, $P<0 \cdot 05)$; and positively correlated with BMI at all stages of the study ( $r 0.248$ to $0.353, P<0.05$ ).

\section{Discussion}

Natural dietary sources of folate remain important for preventing folate deficiency in those countries where staple food fortification with folic acid is not mandatory (e.g. Australia) or prohibited (e.g. The Netherlands). There is some justifiable concern that natural dietary sources may not provide an adequately large and reliable intake of folate to prevent developmental and degenerative diseases caused by sub-optimal intakes, because of uncertainty over the folate content of foods as well as the bioavailability (absorbed fraction that can be used metabolically) and bioefficacy (relative effect on a functional parameter such as prevention of

Table 4. Comparison of plasma folate $(\mathrm{nmol} / \mathrm{l})$, red-cell folate $(\mathrm{nmol} / \mathrm{l})$ and plasma homocyst(e)ine ( $\mu$ mol/l) during the stages of the intervention within and between dietary groups

(Values are arithmetic means and their $95 \% \mathrm{Cl}$ )

\begin{tabular}{|c|c|c|c|c|c|c|c|}
\hline & \multicolumn{2}{|c|}{ PCS group ( $n 25)$} & \multicolumn{2}{|c|}{ ALF group ( $n 25)$} & \multicolumn{2}{|c|}{ FA group (n 18) } & \multirow[b]{2}{*}{$P($ ANOVA $) \dagger$} \\
\hline & Mean & $95 \% \mathrm{Cl}$ & Mean & $95 \% \mathrm{Cl}$ & Mean & $95 \% \mathrm{Cl}$ & \\
\hline \multicolumn{8}{|c|}{ Plasma folate $(\mathrm{nmol} / \mathrm{l})$} \\
\hline Baseline & $12 \cdot 7$ & $10 \cdot 5,14 \cdot 9$ & $12 \cdot 9$ & $9 \cdot 9,15 \cdot 7$ & $17 \cdot 5$ & $13 \cdot 2,21 \cdot 8$ & 0.0618 (NS) \\
\hline 4 weeks & 11.9 & $9 \cdot 6,14 \cdot 3$ & $21 \cdot 6$ & $17 \cdot 5,25 \cdot 7^{\star \star \star}$ & 30.9 & $25 \cdot 9,35 \cdot 9^{\star \star \star}$ & $<0.0001$ \\
\hline 8 weeks & $11 \cdot 7$ & $9 \cdot 0,14 \cdot 5$ & $25 \cdot 8$ & $21 \cdot 2,30 \cdot 4^{\star \star \star}$ & 35.9 & $31 \cdot 7,40 \cdot 0^{\star \star \star}$ & $<0.0001$ \\
\hline 12 weeks & $13 \cdot 6$ & $10 \cdot 7,16 \cdot 3$ & $25 \cdot 0$ & $20 \cdot 7,29 \cdot 3^{\star \star \star}$ & $36 \cdot 1$ & $32 \cdot 5,39 \cdot 6^{\star \star \star}$ & $<0.0001$ \\
\hline 16 weeks & $13 \cdot 6$ & $10 \cdot 8,16 \cdot 3$ & $27 \cdot 1$ & $22 \cdot 5,31 \cdot 7^{\star \star \star}$ & $40 \cdot 1$ & $35 \cdot 0,45 \cdot 1^{\star \star *}$ & $<0.0001$ \\
\hline$P($ ANOVA $) \ddagger$ & 0.6373 & NS & $<0.0001$ & $<0.0001$ & $<0.0001$ & $<0.0001$ & \\
\hline \multicolumn{8}{|c|}{ Red-cell folate $(\mathrm{nmol} / \mathrm{l})$} \\
\hline Baseline & 497 & 414,581 & 509 & 434,584 & 572 & 438,706 & 0.7768 (NS) \\
\hline 4 weeks & 453 & 390,516 & 538 & 477,599 & 581 & 498,663 & 0.0105 \\
\hline 8 weeks & 496 & 422,469 & 637 & 557,717 & 729 & $644,815^{\star}$ & $<0.0001$ \\
\hline 12 weeks & 594 & 489,700 & 803 & $693,912^{\star \star \star}$ & 1025 & $909,1142^{\star \star \star}$ & $<0.0001$ \\
\hline 16 weeks & 578 & 481,673 & 768 & $676,860^{\star \star \star}$ & 999 & $881,1118^{\star \star \star}$ & $<0.0001$ \\
\hline$P($ ANOVA $) \ddagger$ & 0.0810 & NS & $<0.0001$ & $<0.0001$ & $<0.0001$ & $<0.0001$ & \\
\hline \multicolumn{8}{|c|}{ Plasma homocyst(e)ine ( $\mu \mathrm{mol} / \mathrm{l})$} \\
\hline Baseline & $9 \cdot 7$ & $8 \cdot 2,11 \cdot 1$ & $9 \cdot 1$ & $8 \cdot 2,10 \cdot 0$ & $8 \cdot 1$ & $7 \cdot 4,8.9$ & 0.1271 (NS) \\
\hline 4 weeks & $9 \cdot 3$ & $7 \cdot 5,11 \cdot 1$ & 7.9 & $7 \cdot 1,8 \cdot 7$ & $6 \cdot 5$ & $5 \cdot 7,7 \cdot 3^{\star}$ & 0.0018 \\
\hline 8 weeks & 9.5 & $7 \cdot 0,11 \cdot 9$ & $6 \cdot 8$ & $6 \cdot 3,7 \cdot 3^{\star \star *}$ & $6 \cdot 6$ & $5 \cdot 9,7 \cdot 3$ & 0.0014 \\
\hline 12 weeks & 8.9 & $7 \cdot 5,10 \cdot 4$ & $7 \cdot 1$ & $6 \cdot 3,7 \cdot 9^{\star \star}$ & $6 \cdot 5$ & $5 \cdot 6,7 \cdot 3^{\star}$ & 0.0011 \\
\hline 16 weeks & $8 \cdot 3$ & $7 \cdot 0,9 \cdot 6$ & $6 \cdot 8$ & $6 \cdot 2,7 \cdot 5^{\star \star *}$ & $6 \cdot 0$ & $5 \cdot 4,6 \cdot 6^{\star \star}$ & 0.0008 \\
\hline$P($ ANOVA $) \ddagger$ & 0.5092 & NS & $<0.0001$ & $<0.0001$ & 0.0017 & 0.0017 & \\
\hline
\end{tabular}

Treatment groups: PCS group, subjects received bread made with pericarp seed coat (PCS) flour plus placebo tablet (low-folate control); ALF group, subjects received bread made with aleurone flour (ALF) plus placebo tablet; FA group, subjects received PCS bread plus folic acid tablet (high-folate control).

Mean values were significantly different for comparison against baseline within the same group: ${ }^{\star} P<0.05,{ }^{\star \star} P<0.01,{ }^{\star \star \star} P<0.001$.

† Comparison across groups based on log-transformed data.

$\ddagger$ Comparison within group based on log-transformed data. 
(a)

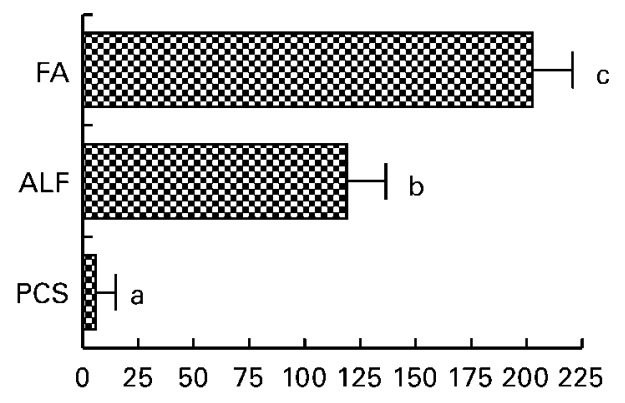

$\%$ plasma folate change relative to baseline

(b)

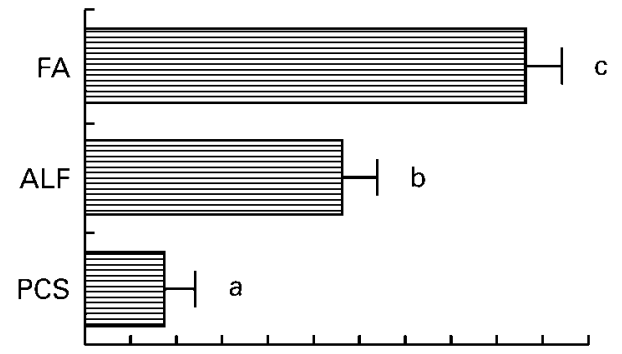

$0 \quad 102030 \quad 405060708090100110$

$\%$ red-cell folate change relative to baseline

(c)

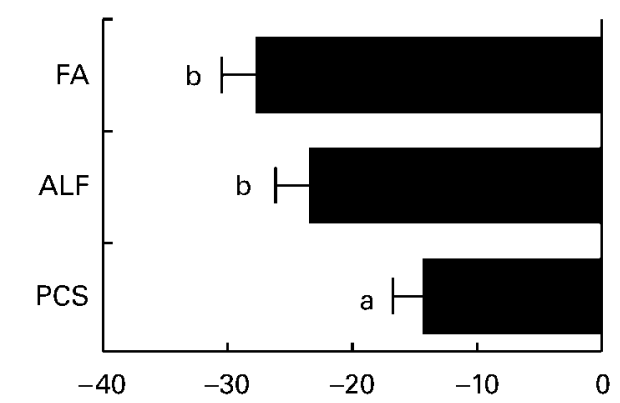

$\%$ plasma homocyst(e)ine change relative to baseline

Fig. 2. Percentage change in (a) plasma folate, (b) red-cell folate and (c) plasma homocyst(e)ine at 16 weeks relative to baseline. Percentage change was adjusted for baseline value. FA, ALF and PCS refer to the treatment groups: FA group, subjects $(n 18)$ received bread made with pericarp seed coat (PCS) flour plus folic acid tablet (high-folate control); ALF group, subjects ( $n$ 25) received bread made with aleurone flour (ALF) plus placebo tablet; PCS group, subjects $(n 25)$ received PCS bread plus placebo tablet (low-folate control). Values are means with standard errors shown by horizontal bars. Mean values with unlike superscript letters were significantly different by ANOVA: (a) $P<0.0001$, (b) $P<0.0001$, (c) $P=0.0034$.

chromosome breaks or lowering of homocyst(e)ine) of natural folate (Cuskelly et al. 1996; Brouwer et al. 1999; Fenech, 2001; Melse-Boonstra et al. 2004). It is therefore important to identify dietary sources that are naturally high in folate and have a high bioavailability and bioefficacy relative to folic acid supplementation.

Wheat aleurone flour is a novel food product that has the potential to make an important contribution to intake of natural folate. The aleurone cells, together with the germ, contain the wheat grain's essential nutrients required for the growth and development of the embryo (Saxelby \& Venn-Brown, 1980; Clysedale, 1994). One of the most notable features of the composition of this product is the high level of folate, which is present at a concentration $>500 \mu \mathrm{g} / 100 \mathrm{~g}$ wet ALF. This natural level of folate is higher than that observed in wheat bran, fruits and vegetables (usually between 20 and $200 \mu \mathrm{g} / 100 \mathrm{~g}$ wet weight; Subar et al. 1989; Bailey, 1995) and is comparable to folate/folic acid levels in fortified flour and cereal that provide $50 \%$ of the RDA per serving (assuming an RDA of $400 \mu \mathrm{g}$ and a serving size of $40 \mathrm{~g}$ wet weight; Crane et al. 1995). The results from the present study show for the first time that moderate intake of ALF is an effective strategy for raising red-cell folate and lowering plasma homocys$\mathrm{t}(\mathrm{e})$ ine in individuals who were selected for their relatively low red-cell folate and relatively high plasma homocyst(e)ine.

It has previously been thought that bioavailability and bioefficacy of natural folate are strongly limited by polyglutamation. However, there is a growing body of evidence indicating that certain natural sources of folate may have bioavailability and bioefficacy values $>50 \%$ relative to that of synthetic folic acid. For example, results from the present study can be compared with those of Brouwer et al. (1999), who examined the effect of increasing folate intake from a baseline of $210 \mu \mathrm{g} / \mathrm{d}$ to $560 \mu \mathrm{g} / \mathrm{d}$, by controlled increased citrus fruit and vegetable intakes over a 4-week period, on changes in plasma folate and homocyst(e)ine. Their results showed an increase of $6.5 \mathrm{nmol} / \mathrm{l}$ in plasma folate and a decrease of $1.5 \mu \mathrm{mol} / 1$ in plasma homocyst(e)ine. The present study at 4 weeks showed an increase of $8.7 \mathrm{nmol} / 1$ in plasma folate and a decrease in plasma homocys$\mathrm{t}(\mathrm{e})$ ine of $1.2 \mu \mathrm{mol} / \mathrm{l}$ in the ALF group, who had a higher intake of folate (i.e. $836 \mu \mathrm{g} / \mathrm{d}$ ). From their results Brouwer et al. (1999) estimated the bioavailability of folate from the vegetables and citrus fruit relative to supplemental folic acid $(250 \mu \mathrm{g} / \mathrm{d})$ to be $78 \%$ based on plasma folate. A more recent study (Melse-Boonstra et al. 2004) determined the bioavailability and bioefficacy of heptaglutamyl folate (one of the natural polyglutamated folate forms commonly found in foods) relative to monoglutamyl folate in men and women aged 50-75 years after 12 weeks at daily supplement intake levels of 142 and $320 \mu \mathrm{g}$, respectively. These results showed that the bioavailability of heptaglutamyl folic acid relative to monoglutamyl folic acid was $68 \%$ on the basis of red-cell folate and bioefficacy based on plasma homocys$\mathrm{t}(\mathrm{e})$ ine was $106 \%$.

Due to the relatively large differences between additional natural folate intake from bread in the ALF group relative to the FA group (i.e. $404 \mu \mathrm{g} / \mathrm{d}$ ) and the additional folic acid intake from the tablet in the FA group $(608 \mu \mathrm{g} / \mathrm{d})$, and because intakes of folic acid $>400 \mu \mathrm{g} / \mathrm{d}$ are likely to maximise the homocyst(e)ine-lowering effect (van Oort et al. 2003), it was not possible to calculate accurately the bioavailability and bioefficacy of ALF. Nevertheless, it is evident that a relatively small daily intake of ALF bread (containing approximately $67 \mathrm{~g}$ ALF) can produce a homocyst(e)ine-lowering effect that is of a similar magnitude to that produced by a high-dose folic acid tablet supplement, which suggests that natural folate in ALF has a high level of bioavailability and bioefficacy. An earlier study, in which we compared intake of $515 \mu \mathrm{g}$ natural folate from ALF and $500 \mu \mathrm{g}$ folic acid in a tablet by measuring the area under the plasma folate concentration $v$. time curve over a period of $7 \mathrm{~h}$ after consumption, suggested that the bioavailability of folate from ALF was similar to that of folic acid (Fenech et al. 1999). The decline in plasma homocyst(e)ine in the ALF group $(-2.3 \mu \mathrm{mol} / \mathrm{l})$ is greater than that observed in 50-70 year old men supplemented with $700 \mu \mathrm{g} / \mathrm{d}$ or $200 \mu \mathrm{g} / \mathrm{d}$ folic acid $(-0.8 \mu \mathrm{mol} / \mathrm{l})$ and compar- 
able to that for young adults supplemented with $7 \mu \mathrm{g} / \mathrm{d}$ vitamin B12 and $700 \mu \mathrm{g} / \mathrm{d}$ folic acid $(-2.7 \mu \mathrm{mol} / \mathrm{l})$ over a similar intervention period (base-line plasma homocyst(e)ine was almost the same between these studies, 9.1-9.4 $\mu \mathrm{mol} / \mathrm{l}$ ) (Fenech et al. 1997, 1998). A meta-analysis of twelve clinical trials with folic acid involving 1114 people estimated that supplementation with folic acid (500-5000 $\mu \mathrm{g} / \mathrm{d})$ should reduce plasma homocyst(e)ine by $23 \%$ in subjects who had folate $(12 \mathrm{nmol} / \mathrm{l})$ and homocys$\mathrm{t}(\mathrm{e})$ ine $(12 \mu \mathrm{mol} / \mathrm{l})$ in plasma before treatment (Homocyst(e)ine Lowering Trialists' Collaboration, 1998). Subjects in the ALF group in the present study had an additional natural folate intake of $404 \mu \mathrm{g} / \mathrm{d}$ from ALF, a pre-intervention plasma folate of $12.9 \mathrm{nmol} / \mathrm{l}$, a plasma homocyst(e)ine of $9.1 \mu \mathrm{mol} / 1$ and a $25 \%$ reduction (adjusted for baseline) in plasma homocyst(e)ine, which is similar to the estimated effect for $500-5000 \mu \mathrm{g}$ folic acid daily in the meta-analysis.

Mandatory fortification of flour with folic acid has proved to be an effective and reliable method of preventing folate deficiency and possibly diseases caused by folate deficiency such as neural tube defects (Honein et al. 2001). It is clear from the results of the present study that ALF has the potential to be a practical alternative to folic acid fortification that may be useful in those countries in which folic acid fortification is either not mandatory or prohibited, and for those sections of the community who may have a preference for eating natural sources of folate. ALF is also a rich source of a wide range of vitamins, minerals and amino acids required for cell growth and maintenance which may provide additional health benefits to those given by fortification with folic acid alone (Hinton et al. 1953; Saxelby \& VennBrown, 1980). A direct comparison of ALF bread and bread made with folic acid-fortified flour is required to determine the relative performance of ALF bread for optimising folate status as well as other measures of health status such as immune response and genome stability. In the interim, the possibility of inter-individual differences in deconjugation and absorption of polyglutamated folate and the variation in folate content of foods depending on cultivar, field conditions and method of preparation should caution against relying solely on natural foods to correct folate deficiency in the general population. In conclusion, it is evident from the results of the present study that ALF is a good source of bioavailable folate that can, at moderate intake levels, increase tissue folate and reduce plasma homocyst(e)ine substantially in man.

\section{Acknowledgements}

The following CSIRO personnel are thanked for their valuable contributions: Felicia Bulman, with Carolyn Salisbury's assistance, analysed the blood samples for folate and vitamin $B_{12}$. Ben Brinkman for performing the plasma homocyst(e)ine assays. Rodney Trimble for coordinating and performing analyses of the bread samples. Rosemary McArthur is acknowledged for blood collections. Anne McGuffin and Kay Pender arranged appointments for the volunteers at the clinic, coordinated the supply of bread and tablets, and ensured that the food records were completed as required. Dr Tony Bird for providing valuable advice regarding the composition data of the breads. Dr Jayashree Arcot (University of New South Wales) is thanked for her assistance in measuring folate in the bread using the tri-enzyme method. Blackmore's Ltd is thanked for providing the tablets.
Nick Stenvert and Wendy Morgan are duly acknowledged for their advice during the planning stages of the study. Goodman Fielder Milling and Baking Pty Ltd is thanked for supplying the breads. This research was partly funded by a grant-in-aid from Goodman Fielder Milling and Baking Pty Ltd.

\section{References}

Association of Official Analytical Chemists International (1996) Official Methods of Analysis of AOAC International, Vol. II, pp. 41-46 [P Cunniff, editor]. Gaithersburg, MD: AOAC International II.

Bailey LB (1995) Folate requirements and dietary recommendations. In Folate in Health and Disease, pp. 123-151 [LB Bailey, editor]. New York: Marcel Dekker Inc.

Blount BC, Mack MM, Wehr CM, MacGregor JT, Hiatt RA, Wang G, Wickramasinghe SN, Everson RB \& Ames BN (1997) Folate deficiency causes uracil misincorporation into human DNA and chromosome breakage: implications for cancer and neuronal damage. Proc Natl Acad Sci USA 94, 3290-3295.

Bonassi S, Hagmar L, Strombery U, et al. (2000) Chromosomal aberrations in lymphocytes predict human cancer independently of exposure to carcinogens. Cancer Res 60, 1619-1625.

Boushey CJ, Beresford SA, Omenn GS \& Motulsky AG (1995) A quantitative assessment of plasma homocyst(e)ine as a risk factor for vascular disease: probable benefits of increasing folic acid intakes. J Am Med Assoc 274, 1049-1057.

Brouwer IA, van Dusseldorp M, West CE, Meyboorn S, Thomas CMG, Duran M, van het Hof KH, Eskes TK, Hautvast J \& Steegers-Theunissen RPM (1999) Dietary folate from vegetables and citrus fruit decreases plasma homocyst(e)ine concentrations in humans in a dietary controlled trial. J Nutr 129, 1135-1139.

Chambers JC, Ueland PM, Obeid OA, Wrigley J, Refsum H \& Kooner S (2000) Improved vascular endothelial function after oral B vitamins an effect mediated through reduced concentrations of free plasma homocyst(e)ine. Circulation 102, 2479-2483.

Clysedale FM (1994) Optimising the diet with whole grains. Crit Rev Food Sci Nutr 34, 453-471.

Cooper RA \& Jandl JH (1972) Destruction of erythrocytes. In Hematology, pp. 178-191 [WJ Williams, E Beutler, AJ Erslev and RW Rundles, editors]. New York: McGraw-Hill.

Crane CT, Wilson DB, Cook DA, Lewis CJ, Yetley EA \& Rader JI (1995) Evaluating food fortification options: general principles revisited with folic acid. Am J Public Health 85, 660-666.

Cuskelly GJ, McNulty H \& Scott JM (1996) Effect of increasing dietary folate on red cell folate: implications for prevention of neural tube defects. Lancet 347, 657-659.

Czeizel AE \& Dudas I (1992) Prevention of first occurrence of neural tube defects by periconceptional vitamin supplementation. $N$ Engl J Med 327, 32-35.

Daly S, Mills JL, Molloy AM, Conley M, Lee YJ, Kirke PN, Weir DG \& Scott JM (1997) Minimum effective dose of folic acid for food fortification to prevent neural tube defects. Lancet 350, 1666-1669.

Daugherty CE \& Lento HG (1983) Chloroform-methanol extraction method for determination of fat in foods: collaborative study. $J$ Assoc Off Anal Chem 66, 927-932.

Fenech M (2001) The role of folic acid and vitamin $B_{12}$ in genomic stability of human cells. Mutation Res 475, 56-67.

Fenech M, Aitken C \& Rinaldi J (1998) Folate, vitamin B 12 , homocysteine status and DNA damage in young Australian adults. Carcinogenesis 19, 1163-1171.

Fenech M, Dreosti IE \& Rinaldi JR (1997) Folate, vitamin B 12 , homocys$\mathrm{t}(\mathrm{e})$ ine status and chromosome damage rate in lymphocytes of older men. Carcinogenesis 18, 1329-1336.

Fenech M, Noakes M, Clifton P \& Topping D (1999) Aleurone flour is a rich source of bioavailable folate in humans. $J$ Nutr 129, 1114-1119. 
Gregory JF (1995) The bioavailability of folate. In Folate in Health and Disease, pp. 195-235 [LB Bailey, editor]. New York: Marcel Dekker Inc.

Helsinki Declaration (1996) Nuremberg doctor's trial. Declaration of Helsinki. Br Med J 313, 1448-1449.

Hinton JJ, Peers FG \& Shaw B (1953) The B vitamins in wheat - the unique aleurone layer. Nature 172, 993-995.

Holland B, Welch AA, Unwin ID, Buss DH, Paul AA \& Southgate DAT (1995) McCance and Widdowson's: The Composition of Foods, 5th ed., London: HMSO.

Homocyst(e)ine Lowering Trialists' Collaboration (1998) Lowering blood homocyst(e)ine with folic acid based supplements: meta-analysis of randomised trials. Br Med J 316, 894-898.

Honein MA, Paulozzi LJ, Mathews TJ, Erickson JD \& Wong LY (2001) Impact of folic acid fortification of the US food supply on the occurrence of neural tube defects. $J$ Am Med Assoc 285, 2981-2986.

Kang SS, Wong PWK \& Malinow MR (1992) Hyperhomocyst(e)inemia as a risk factor for occlusive vascular disease. Annu Rev Nutr 12, 279-298.

Kirsten WJ \& Hesselius GU (1983) Rapid, automatic, high capacity Dumas detection of nitrogen. Microchem J 28, 529-547.

Law M (2000) Fortifying food with folic acid. Semin Thromb Hemost 26, 349-352.

McCleary BV, Solah V \& Gibson TS (1994) Quantitative measurement of total starch in cereal flours and products. J Cereal Sci 20, 51-58.

Melse-Boonstra A, West CE, Katan MB, Kok FJ \& Verhoef P (2004) Bioavailability of heptaglutamyl relative to monoglutamyl folic acid in healthy adults. Am J Clin Nutr 79, 424-429.

Molloy AM, Daly S, Mills JL, Kirke PN, Whitehead AS, Ramsbottom D, Conley MR, Weir DG \& Scott JM (1997) Thermolabile variant of 5,10methylenetetrahydrofolate reductase associated with low red cell folates: implications for folate intake recommendations. Lancet $\mathbf{3 4 9}$, $1591-1593$.

MRC Vitamin Study Research Group (1991) Prevention of neural tube defects: results from the Medical Research Council Vitamin Study. Lancet 338, 313-317.

Prosky L, Asp NG, Furda I, DeVries JW, Schweizer TF \& Harland BF (1985) Determination of total dietary fibre in foods and food products: collaborative study. J Assoc Off Anal Chem 68, 677-679.

Rader JI, Weaver CM \& Angyal G (1998) Use of microbiological assay with tri-enzyme extraction for measurement of pre-fortification levels of folates in enriched cereal-grain products. Food Chem 62, $451-465$.

Rasmussen LB, Ovesen L, Bulow I, Knudsen N, Laurberg P \& Perrild H (2000) Folate intake, lifestyle factors and homocyst(e)ine concentrations in younger and older women. Am J Clin Nutr 72, 1156-1163.

Rong N, Selhub J, Goldin BR \& Rosenberg IH (1991) Bacterially synthesized folate in rat large intestine is incorporated into host tissue folyl polyglutamates. J Nutr 121, 1955-1959.

Rosenberg IH \& Rosenberg LE (1998) The implications of genetic diversity for nutrient requirements: the case of folate. Nutr Rev 56, S47-S53.

Rydlewicz A, Simpson JA, Taylor RJ, Bond CM \& Golden MHM (2002) The effect of folic acid supplementation on plasma homocysteine in an elderly population. $Q J$ Med $\mathbf{9 5}, 27-35$.

Saxelby C \& Venn-Brown U (1980) The structure and composition of the wheat grain. In The Role of Australian Flour and Bread in Health and Nutrition, pp. 37-41. Chatswood, NSW: Glenburn Pty Ltd.

Scheelings P (1996) Prospects for measuring folates in Australian foods. Aust J Nutr Diet 53, S23-S28.

Shrestha AK, Arcot J \& Paterson J (2000) Folate assay by traditional and tri-enzyme treatments using cryoprotected Lactobacillus casei. Food Chem 71, 545-552.

Stenvert N (1995) New high fibre bread - Farrer's Gold. Food Aust 47, 462-463.

Stenvert N (1997) Novel natural products from grain fractionation. In Cereals - Novel Uses and Processes, pp. 241-245 [GM Cambell, C Webb and SL McKee, editors]. New York: Plenum Press.

Stevenson RE, Allen WP, Pai GS, Best R, Seaver RH, Dean J \& Thompson S (2000) Decline in prevalence of neural tube defects in a high-risk region of the United States. Pediatrics 106, 677-683.

Subar AF, Block G \& James LD (1989) Folate intake and food sources in the US population. Am J Clin Nutr 50, 508-516.

Tamura T, Mizuno Y, Jhonson KE \& Jacob RA (1997) Food folate assay with protease, $\alpha$-amylase, and folate conjugase treatments. J Agric Food Chem 45, 135-139.

Theander O \& Westerlund E (1986) Improved procedures for the analysis of dietary fibre. J Agric Food Chem 34, 330-336.

van Oort FVA, Melse-Boonstra A \& Brouwer IA (2003) Folic acid and plasma homocysteine reduction in older adults: a dose-finding study. Am J Clin Nutr 77, 1318-1323.

Vester B \& Rasmussen K (1991) High performance liquid chromatography method for rapid and accurate determination of homocyst(e)ine in plasma and serum. Eur J Clin Chem Clin Biochem 29, 549-554.

Vickers AJ \& Altman DG (2001) Analysing controlled trials with baseline and follow-up measurements. Br Med J 323, 1123-1124.

Wagner C (1995) Biochemical role of folate in cellular metabolism. In Folate in Health and Disease, pp. 23-42 [LB Bailey, editor]. New York: Marcel Dekker Inc. 